\title{
Penentuan Kriteria Pengembangan Agrowisata di Kecamatan Sukapura Kabupaten Probolinggo
}

\author{
Suryadi Muchlis dan Eko Budi Santoso \\ Departemen Perencanaan Wilayah dan Kota, Fakultas Teknik Sipil dan Perencanaan, Institut Teknologi \\ Sepuluh Nopember (ITS) \\ e-mail: eko_budi@urplan.its.ac.id
}

\begin{abstract}
Abstrak-Kecamatan Sukapura dalam RTRW Kab. Probolinggo Tahun 2010-2029 diarahkan sebagai agrowisata. Kecamatan ini memiliki sumber daya lokal yang berpotensi untuk mendukung pengembangan agrowisata, baik dari sumber daya alam meliputi komoditas pertanian, kondisi alam dan iklim maupun sumber daya manusia seperti kemampuan dan kualiatas masyarakat serta budaya yang dimiliki masyarakat. Namun faktanya agrowisata di kecamatan sukapura belum memanfaatkan potensi sumber daya lokal secara optimal. Untuk itu diperlukan penelitian untuk menentukan kriteria pengembangan agrowisata di Kecamatan Sukapura sehingga potensi sumber daya lokal yang ada dapat teroptimalkan dengan baik dalam mendukung pengembangan agrowisata di Kecamatan Sukapura. Dalam proses analisis dibagi menjadi dua tahapan yaitu analisis konten dan order analysis. Analisis konten menggunakan input data berupa transkip wawancara, sedangkan order analysis menggunakan input berupa hasil kuisioner skala guttman. Hasil akhir dari penelitian ini yaitu kriteria pengembangan agrowisata yang terdari dari variabel atraksi dan jenis komoditas pertanian, objek wisata lain, fasilitas, infrastruktur, kerjasama, transportasi, ketahanan bencana, sikap dan keramahan masyarakat, dan produk agrowisata.
\end{abstract}

Kata Kunci-Agrowisata, Sukapura, Order Analysis.

\section{PENDAHULUAN}

$\mathrm{K}$ ESENJANGAN pembangunan yang bias ke perkotaan memunculkan konsep-konsep pengembangan wilayah yang terfokus pada perdesaan. Agrowisata merupakan salah satu konsep pengembangan wilayah perdesaan yang mengedepankan aktivitas pertanian dan suasana pedesaan yang masih alami sebagai daya tarik wisatanya, serta mengedepankan aspek kehidupan masyarakat, kelestarian sumber daya alam dan lingkungan. Selain itu, konsep agrowisata dapat memberi peluang bagi petani lokal untuk meningkatkan pendapatan, membuka peluang usaha dan kesempatan kerja bagi masyarakat, sekaligus menjaga dan melestarikan kekayaan alam dan hayati.

RTRW Kabupaten Probolinggo Tahun 2010-2029, Kecamatan Sukapura merupakan salah satu kecamatan yang diarahkan sebagai agrowisata [1]. Kecamatan ini memiliki sumber daya lokal yang dapat mendukung pengembangan agrowisata. Diantara sumber daya lokal tersebut seperti jenis tanah vulkanis di Kecamatan Sukapura yang banyak mengandung mineral yang berasal dari ledakan gunung berapi yang berupa pasir dan batu, lumpur bercampur dengan tanah liat yang berwarna kelabu kekuningan. Sifat tanah semacam ini mempunyai tingkat kesuburan yang tinggi, sehingga cocok apabila di tanami sayur-sayuran. Hal tersebut membuat kecamatan ini memiliki jenis komoditas pertanian yang beragam seperti padi, jagung, kentang, kubis, bawang daun, wortel, tomat, dan sawi. Tidak hanya dari komoditas pertanian saja, pada komoditas perkebunan terdapat tanaman cengkeh dan kopi yang merupakan komoditas basis dari kecamatan ini. Pada komoditas peternakan terdapat jenis ternak kuda, babi, dan ayam ras yang juga menjadi komoditas basis di Kecamatan Sukapura [2]. Selain itu, iklim dan keindahan alam kecamatan ini dapat mendukung pengembangan suatu kawasan wisata, udara yang sejuk serta panorama hamparan pertanian sayuran yang tersebar di Kecamatan Sukapura dapat menjadi daya tarik wisata. Hampir setengah dari wilayah Kecamatan Sukapura $(39.65 \%)$ merupakan lahan tegalan yang ditanami berbagai macam tanaman sayuran dengan bentuk lahan yang tidak landai (94.62\%) atau didominasi oleh bentuk lahan berbukit. Dan suhu rata-rata Kecamatan Sukapura sekitar $20^{\circ} \mathrm{C}$, bahkan pada saat tertentu dapat mencapai dibawah $0^{\circ} \mathrm{C}$, dapat menciptakan rasa nyaman bagi wisatawan [3].

Dari sumber daya manusia, tidak berbeda dengan wilayah perdesaaan pada umumnya, Kecamatan Sukapura, didominasi oleh masyarakat yang bekerja di bidang pertanian baik sebagai petani maupun buruh tani, sekitar (86.03\%). Selain itu, keberadaan objek wisata alam Gunung Bromo telah mendorong masyarakat di Kecamatan Sukapura untuk bergerak dibidang kepariwisataan. Terdapat masyarakat yang bekerja di bidang angkutan wisata seperti menjadi supir jeep, ojek wisata, dan joki kuda. bahkan bekerja dibidang perhotelan dan membuka penginapan atau homestay. Selain itu, kecamatan yang termasuk dalam kawasan pegunungan bromo-tengger ini terdapat keberadaan masyarakat Suku Tengger. Masyarakat suku tengger memiliki budaya atau tradisi yang unik dan khas. Berbagai jenis tradisi seperti perayaan hari besar dan upacara-upacara adat seperti upacara adat yadnya kasodo, upacara adat unan-unan, upacara adat pujan kasanga, upacara adat entas-entas, upacara ada penganten walaga, upacara karo, dan ruwatan [4]. Hal ini tentu dapat menjadi daya tarik kawasan dan dapat mendukung pengembangan agrowisata di Kecamatan Sukapura.

Selain itu, perbedaan Kecamatan Sukapura dibandingkan dengan kecamatan lain di Kab. Probolinggo ialah kecamatan ini merupakan pintu masuk objek wisata terkenal gunung bromo. Berdasarkan data BPS Kabupaten Probolinggo tahun 2016, 40 $\%$ wisatawan yang berkunjung ke wisata di Kabupaten 
Probolinggo diserap oleh objek wisata terkenal ini [3]. Ditambah lagi, juga terdapat beberapa objek wisata lain seperti bukit mentigen yang memiliki pemandangan alam indah, air terjun umbulan, gua lowo atau gua kelelawar yang unik, desa wisata seruni yang menampilkan aktivitas masyarakat suku tengger [4]. Hal ini tentu dapat mendukung pengembangan agrowisata yang merupakan jenis wisata yang relatif baru, sehingga lokasi objek wisata yang terletak di daerah wisata terkenal tentunya akan menambah tingkat potensi objek wisata agro. Dimana dapat memanfaatkan potensi kunjungan wisatawan untuk ikut berkujung ke kawasan Agrowisata.

Pada tahun 2010 dibangun suatu agrowisata dengan memanfaatkan tanaman stroberi. Pengembangan agrowisata ini merupakan inisiasi dari kelompok tani di Desa Jetak. Lokasi kawasan agrowisata ini cukup strategis dan tidak sulit menemukannya sebab tepat berada dijalur menuju objek wisata alam gunung bromo. Namun, diakhir tahun 2010 terjadi erupsi gunung bromo yang berlangsung hingga bulan April 2011. Hal ini mengakibatkan hampir semua tanaman stroberi mati karena tertutup abu dan kekurangan air, hanya tersisa 100 tanaman stroberi. Akhirnya hanya 1 orang dari kelompok tani tersebut yang mencoba mengembangkan kembali agrowisata ini dengan bantuan modal dari pemerintah. Hingga saat ini sudah terdapat 25.000 tanaman stroberi. Agrowisata ini memiliki daya tarik wisata berupa keindahan hamparan kebun stroberi dan kegiatan memetik langsung buah stroberi, sehingga kawasan agrowisata ini dikenal dengan "Agrowisata Petik Stroberi". Agrowisata petik stroberi terus dilakukan pengembangan, saat ini telah terdapat fasilitas pendukung seperti gazebo, toilet, tempat dan tempat parkir. Dan mulai dikembangkan produk olahan stroberi seperti selai, sirup, dan dodol.

Meskipun telah dikembangkan agrowisata dengan memanfaatkan tanaman stroberi di Desa Jetak, namun masih banyak sumber daya lokal lainnya yang dapat dikembangkan sebagai agrowisata. Hal ini sesuai dengan pernyataan dari pemilik Agrowisata Petik Stroberi bahwa masih banyak potensi pengembangan agrowisata yang terdapat di Kecamatan Sukapura, baik dari potensi sumber daya alam maupun dari potensi sumber daya manusia. Hingga saat ini, belum terdapat penelitian terkait pengembangan agrowisata di Kecamatan Sukapura khususnya dengan memanfaatkan potensi sumber daya lokal. Oleh sebab itu, perlu dilakukan penelitian terkait kriteria pengembangan agrowisata di Kecamatan Sukapura, sehingga dapat mengoptimalkan potensi sumber daya lokal dalam mendukung pengembangan agrowisata di Kecamatan Sukapura. Kriteria pengembangan agrowisata tersebut selanjutnya dapat digunakan sebagai pertimbangan dalam menentukan arahan pengembangan agrowisata di Kecamatan Sukapura.

\section{METODE PENELITIAN}

\section{A. Pendekatan dan Jenis Penelitian}

Pendekatan yang digunakan dalam penelitian ini adalah pendekatan rasionalistik. [5] Jenis penelitian dalam penelitian ini adalah deskriptif kualitatif-kuantitatif.

\section{B. Variabel Penelitian}

Variabel penelitian yang digunakan untuk menentukan kriteria pengembangan agrowisata di Kecamatan Sukapura Kabupaten Probolinggo antara lain atraksi, jenis komoditas pertanian, fasilitas, infrastruktur, transportasi \& aksesibilitas, sikap dan keramahan masyarakat, cara promosi, luas lahan, sumber keuangan dan modal, ketahanan bencana [6]. Variabel ini memikili kemungkinan untuk tereduksi atau muncul variabel baru berdasarkan hasil analisis variabel terkait pengembangan agrowisata.

\section{Metode Pengumpulan Data}

Metode pengumpulan data yang digunakan dalam penelitian ini adalah teknik survei primer yang terdiri dari wawancara dan kuisioner. Pengumpulan data melalui wawancara, berjenis wawancara semi terstruktur kepada stakeholders yaitu Kepala Seksi Destinasi Wisata Bidang Kepariwisataan Dinas Pariwisata Kabupaten Probolinggo (S1), Staf Bagian Fisik-Prasarana Badan Perencanaan dan Pembangunan Daerah Kabupaten Probolinggo (S2), Pengelola Agrowisata Petik Stroberi Desa Jetak Kecamatan Sukapura (S3). Sedangkan pengumpulan data melalui kuisioner, jenis kuisioner ialah kuisioner skala guttman yang disebarkan kepada masyarakat Kecamatan Sukapura yang diwakili oleh Petani di Kecamatan Sukapura. Penentuan ukuran sampel atau responden menggunakan rumus slovin dengan populasi petani sekitar 12.301 jiwa dan signifikansi atau error $10 \%$, dengan hasil 99.19 dibulatkan menjadi 100 jiwa. Responden terpilih agar lebih tepat sasaran maka dibuatlah kriteria responden sebagai berikut:

- Berdomisili di salah satu desa di Kecamatan Sukapura.

- Telah menetap minimal 5 tahun.

- Berencana menetap 5 tahun mendatang.

- Pernah mengunjungi agrowisata atau mengetahui tentang pengembagan agrowisata.

\section{Metode Analisis}

Metode penelitian yang digunakan dalam menentukan kriteria pengembangan agrowisata terdiri dari 2 (dua) tahapan analisis yaitu tahap pertama menggunakan metode analisis konten (content analysis), digunakan untuk menentukan variabel terkait pengembangan agrowisata di Kecamatan Sukapura Kabupaten Probolinggo. Dan tahap kedua menggunakan metode Order Analysis, digunakan untuk menentukan kriteria pengembangan agrowisata di Kecamatan Sukapura.

\section{HASIL DAN PEMBAHASAN}

Tahap pertama, yaitu menentukan variabel terikait pengembangan agrowisata di Kecamatan Sukapura. Tahap ini, menggunakan teknik analisis yaitu analisis konten dengan input data berupa transkrip wawancara dari stakeholders. Berikut proses penentuan variabel terkait kriteria pengembangan agrowisata di Kecamatan Sukapura. 
Tabel 1.

Penentuan Variabel Terkait Kriteria Pengembangan Agrowista

\begin{tabular}{|c|c|c|c|c|}
\hline \multirow{2}{*}{ Variabel } & \multicolumn{3}{|c|}{ Stakeholder } & \multirow{2}{*}{ Ket. } \\
\hline & S1 & S2 & $\mathbf{S 3}$ & \\
\hline Atraksi & $\begin{array}{l}\text { Disebutkan } \\
5 \text { kali }\end{array}$ & $\begin{array}{l}\text { Tidak } \\
\text { disebutkan }\end{array}$ & $\begin{array}{l}\text { Disebutkan } \\
3 \text { kali }\end{array}$ & Terpilih \\
\hline Fasilitas & $\begin{array}{l}\text { Disebutkan } \\
2 \text { kali }\end{array}$ & $\begin{array}{l}\text { Disebutkan } \\
1 \text { kali }\end{array}$ & $\begin{array}{l}\text { Disebutkan } \\
3 \text { kali }\end{array}$ & Terpilih \\
\hline Infrastruktur & $\begin{array}{l}\text { Tidak } \\
\text { disebutkan }\end{array}$ & $\begin{array}{l}\text { Disebutkan } \\
3 \text { kali }\end{array}$ & $\begin{array}{l}\text { Disebutkan } \\
3 \text { kali }\end{array}$ & Terpilih \\
\hline $\begin{array}{l}\text { Transportasi } \\
\& \\
\text { Aksesibilitas }\end{array}$ & $\begin{array}{l}\text { Disebutkan } \\
1 \text { kali }\end{array}$ & $\begin{array}{l}\text { Disebutkan } \\
1 \text { kali }\end{array}$ & $\begin{array}{l}\text { Tidak } \\
\text { disebutkan }\end{array}$ & Terpilih \\
\hline $\begin{array}{l}\text { Sikap dan } \\
\text { Keramahan }\end{array}$ & $\begin{array}{l}\text { Disebutkan } \\
2 \text { kali }\end{array}$ & $\begin{array}{l}\text { Disebutkan } \\
1 \text { kali }\end{array}$ & $\begin{array}{l}\text { Disebutkan } \\
3 \text { kali }\end{array}$ & Terpilih \\
\hline Masyarakat & & & & \\
\hline Jenis & Disebutkan & Disebutkan & Disebutkan & Terpilih \\
\hline $\begin{array}{l}\text { Komoditas } \\
\text { Pertanian }\end{array}$ & 2 kali & $1 \mathrm{kali}$ & $1 \mathrm{kali}$ & \\
\hline Ketahanan & Disebutkan & Disebutkan & Disebutkan & Terpilih \\
\hline Bencana & 2 kali & 1 kali & 3 kali & \\
\hline Cara Promosi & $\begin{array}{l}\text { Tidak } \\
\text { disebutkan }\end{array}$ & $\begin{array}{l}\text { Tidak } \\
\text { disebutkan }\end{array}$ & $\begin{array}{l}\text { Tidak } \\
\text { disebutkan }\end{array}$ & $\begin{array}{l}\text { Tidak } \\
\text { Terpilih }\end{array}$ \\
\hline Luas Lahan & $\begin{array}{l}\text { Tidak } \\
\text { disebutkan }\end{array}$ & $\begin{array}{l}\text { Tidak } \\
\text { disebutkan }\end{array}$ & $\begin{array}{l}\text { Tidak } \\
\text { disebutkan }\end{array}$ & $\begin{array}{l}\text { Tidak } \\
\text { Terpilih }\end{array}$ \\
\hline $\begin{array}{l}\text { Sumber } \\
\text { Keuangan dan } \\
\text { Modal }\end{array}$ & $\begin{array}{l}\text { Tidak } \\
\text { disebutkan }\end{array}$ & $\begin{array}{l}\text { Tidak } \\
\text { disebutkan }\end{array}$ & $\begin{array}{l}\text { Tidak } \\
\text { disebutkan }\end{array}$ & $\begin{array}{l}\text { Tidak } \\
\text { Terpilih }\end{array}$ \\
\hline Objek Wisata & Disebutkan & Disebutkan & Tidak & Terpilih \\
\hline Lain & 2 kali & $1 \mathrm{kali}$ & disebutkan & $\begin{array}{l}\text { sebagai } \\
\text { variabel } \\
\text { baru }\end{array}$ \\
\hline Kerjasama & $\begin{array}{l}\text { Disebutkan } \\
3 \text { kali }\end{array}$ & $\begin{array}{l}\text { Disebutkan } \\
2 \text { kali }\end{array}$ & $\begin{array}{l}\text { Disebutkan } \\
5 \text { kali }\end{array}$ & $\begin{array}{l}\text { Terpilih } \\
\text { sebagai } \\
\text { variabel } \\
\text { baru }\end{array}$ \\
\hline Produk Agro & $\begin{array}{l}\text { Disebutkan } \\
1 \text { kali }\end{array}$ & $\begin{array}{l}\text { Tidak } \\
\text { disebutkan }\end{array}$ & $\begin{array}{l}\text { Disebutkan } \\
1 \text { kali }\end{array}$ & $\begin{array}{l}\text { Terpilih } \\
\text { sebagai } \\
\text { variabel } \\
\text { baru }\end{array}$ \\
\hline
\end{tabular}

Sumber: Hasil analisis, 2017

Tahap kedua, yaitu menentukan kriteria pengembangan agrowisata di Kecamatan Sukapura. Tahap ini, menggunakan teknik analisis yaitu order analysis dengan input data berupa hasil kuisioner skala guttman. Berikut proses penentuan kriteria pengembangan agrowisata di Kecamatan Sukapura dengan tahapan sebagai berikut.

1. Pembentukan Kriteria Sementara

Kriteria dibentuk pada tiap variabel terpilih dengan mempertimbangkan informasi yang diberikan stakeholder, tinjauan literatur dan kondisi eksisting wilayah penelitian. Berikut kriteria sementara yang terbentuk. Selanjutnya, kriteria sementara yang terbentuk dijadikan kuisioner skala guttman dan disebarkan ke responden. Berikut hasil pembentukan kriteria sementara dan rekapan hasil kuisioner.

Tabel 2.

Pembentukan Kriteria Sementara Pengembangan Agrowisata di Kecamatan Sukapura

\begin{tabular}{ccclc}
\hline \hline No. & Variabel & No. & \multicolumn{1}{c}{ Kriteria Sementara } & $\sum \mathbf{( \% )}$ \\
\hline 1. & Atraksi & 1. & $\begin{array}{l}\text { Memiliki keindahan alam dan } \\
\text { hamparan lahan pertanian }\end{array}$ & 100 \\
& 2. & $\begin{array}{l}\text { Menujukan budaya petani dan } \\
\text { aktivitas unik dari pertanian }\end{array}$ & 92 \\
& 3. & $\begin{array}{l}\text { Menyuguhkan kesenian/tradisi } \\
\text { lokal }\end{array}$ & 61 \\
& 4. & Menyuguhkan makanan khas & 77 \\
\hline \hline
\end{tabular}

\begin{tabular}{|c|c|c|c|c|}
\hline No. & Variabel & No. & $\begin{array}{c}\text { Kriteria Sementara } \\
\end{array}$ & $\sum(\mathbf{\%})$ \\
\hline \multirow{4}{*}{2.} & & & penduduk local & \\
\hline & & 5. & $\begin{array}{l}\text { Terdapat outbond dan kegiatan } \\
\text { permainan alam }\end{array}$ & 50 \\
\hline & $\begin{array}{l}\text { Jenis } \\
\text { Komoditas }\end{array}$ & 6. & $\begin{array}{l}\text { Terdapat satu jenis tanaman saja } \\
\text { kawasan agrowisata }\end{array}$ & 14 \\
\hline & Pertanian & 7. & $\begin{array}{l}\text { Terdapat beragam jenis tanaman } \\
\text { pada kawasan agrowisata }\end{array}$ & 99 \\
\hline \multirow[t]{12}{*}{3.} & Fasilitas & 8. & Ketersediaan pos keamanan & 81 \\
\hline & & 9. & Ketersediaan tempat parkir & 96 \\
\hline & & 10. & $\begin{array}{l}\text { Ketersediaan rambu-rambu } \\
\text { petujuk arah dan jalan }\end{array}$ & 100 \\
\hline & & 11. & $\begin{array}{l}\text { Ketersediaan kantor pusat } \\
\text { informasi dan pelayanan }\end{array}$ & 100 \\
\hline & & $12 .$. & Ketersediaan tempat sampah & 93 \\
\hline & & 13. & Ketersediaan toilet/kamar mandi & 100 \\
\hline & & 14. & $\begin{array}{l}\text { Ketersediaan tempat ibadah } \\
\text { berupa musholla }\end{array}$ & 97 \\
\hline & & 15. & $\begin{array}{l}\text { Ketersediaan } \\
\text { hotel/penginapan/tempat } \\
\text { peristirahatan }\end{array}$ & 100 \\
\hline & & 16. & $\begin{array}{l}\text { Ketersediaan kios } \\
\text { cenderamata/kios oleh-oleh }\end{array}$ & 100 \\
\hline & & 17. & Ketersediaan ATM & 93 \\
\hline & & 18. & Ketersediaan pos kesehatan/P3K & 100 \\
\hline & & 19. & $\begin{array}{ll}\begin{array}{l}\text { Ketersediaan } \\
\text { makanan/café }\end{array} & \text { restoran/kedai }\end{array}$ & 93 \\
\hline \multirow[t]{4}{*}{4.} & Kerjasama & 20. & $\begin{array}{l}\text { Kerjasama antar masyarakat } \\
\text { dalam membangun kawasan } \\
\text { agrowisata }\end{array}$ & 16 \\
\hline & & 21. & $\begin{array}{l}\text { Kerjasama masyarakat dengan } \\
\text { investor (swasta) }\end{array}$ & 8 \\
\hline & & 22. & $\begin{array}{l}\text { Kerjasama masyarakat dengan } \\
\text { pemerintah }\end{array}$ & 21 \\
\hline & & 23. & $\begin{array}{l}\text { Kerjasama antara masyarakat, } \\
\text { pemerintah dan investor (swasta) }\end{array}$ & 63 \\
\hline \multirow[t]{3}{*}{5.} & $\begin{array}{l}\text { Sikap dan } \\
\text { Keramahan } \\
\text { Masyarakat }\end{array}$ & 24. & $\begin{array}{l}\text { Memiliki kemampuan dalam } \\
\text { berkomunikasi yang baik dengan } \\
\text { wisatawan }\end{array}$ & 100 \\
\hline & & 25. & 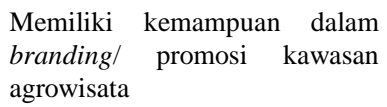 & 100 \\
\hline & & 26. & $\begin{array}{l}\text { Memiliki kemampuan dalam } \\
\text { mengelola kegiatan agrowisata }\end{array}$ & 93 \\
\hline \multirow[t]{3}{*}{6.} & $\begin{array}{l}\text { Transportasi } \\
\text { dan } \\
\text { Aksesibilitas }\end{array}$ & 27. & $\begin{array}{l}\text { Menggunakan transportasi } \\
\text { umum untuk menuju kawasan } \\
\text { agrowisata seperti bus atau } \\
\text { angkutan desa }\end{array}$ & 14 \\
\hline & & 28. & $\begin{array}{l}\text { Menggunakan kendaraan wisata } \\
\text { untuk menuju kawasan } \\
\text { agrowisata seperti jeep dan lain } \\
\text { sebagainya }\end{array}$ & 67 \\
\hline & & 29. & $\begin{array}{l}\text { Menggunakan kendaraan pribadi } \\
\text { untuk menuju kawasan } \\
\text { agrowisata }\end{array}$ & 25 \\
\hline \multirow[t]{4}{*}{7.} & Infrastruktur & 30. & $\begin{array}{l}\text { Perlu terjangkau dengan sinyal } \\
\text { telepon seluler }\end{array}$ & 100 \\
\hline & & 31. & Perlu ketersediaan sumber listrik & 100 \\
\hline & & 32. & Perlu ketersediaan sumber air & 100 \\
\hline & & 33. & Tersedia jaringan jalan & 100 \\
\hline \multirow[t]{3}{*}{8.} & Ketahanan & 34. & Memiliki jalur evakuasi & 92 \\
\hline & Bencana & 35. & $\begin{array}{l}\text { Memiliki tempat melindungi } \\
\text { bibit tanaman }\end{array}$ & 100 \\
\hline & & 36. & $\begin{array}{l}\text { Sumber daya manusia memiliki } \\
\text { kemampuan dalam situasi } \\
\text { tanggap bencana }\end{array}$ & 94 \\
\hline \multirow[t]{2}{*}{9.} & Produk Agro & 37. & $\begin{array}{l}\text { Produk agrowisata berupa } \\
\text { produk olahan hasil pertanian }\end{array}$ & 41 \\
\hline & & 38. & $\begin{array}{l}\text { Produk agrowisata berupa hasil } \\
\text { panen pertanian seperti sayuran/ } \\
\text { buah-buahan. }\end{array}$ & 69 \\
\hline 10. & Wisata & 39. & Mempertimbangkan keberadaan & 80 \\
\hline
\end{tabular}




\begin{tabular}{|c|c|c|c|c|}
\hline No. & Variabel & No. & Kriteria Sementara & $\sum(\mathbf{\%})$ \\
\hline \multirow{2}{*}{\multicolumn{2}{|c|}{ Lain }} & & $\begin{array}{l}\text { objek wisata lain, baik dalam } \\
\text { satu kawasan wisata maupun } \\
\text { tidak (lingkup satu desa) }\end{array}$ & \\
\hline & & 40. & $\begin{array}{l}\text { Tidak perlu mempertimbangkan } \\
\text { objek wisata lain dalam } \\
\text { mengembangkan agrowisata. }\end{array}$ & 20 \\
\hline
\end{tabular}

Sumber: Hasil Analisis, 2017

2. Penggalian dan Konfirmasi Kriteria

Pada proses penggalian dan konfirmasi kriteria pengembangan agrowisata tidak ditemukan kriteria baru pengembangan agrowisata di Kecamatan Sukapura Kabupaten Probolinggo. Oleh sebab itu, terdapat 40 kriteria yang akan menjadi input pengolahan pada proses berikutnya.

3. Perhitungan Skoring

Kriteria yang lolos proses berikutnya merupakan kriteria yang memiliki persentase $\geq 50 \%$, sehingga terdapat 8 kriteria yang tereduksi, sehingga total kriteria yang tersisa sejumlah 32 kriteria, berikut kriteria yang tereduksi yaitu:

Tabel 3.

Beberapa Kriteria yang Tereduksi

\begin{tabular}{|c|c|c|}
\hline No. & Kriteria & $\sum(\%)$ \\
\hline 1. & $\begin{array}{l}\text { Terdapat satu jenis tanaman saja pada kawasan } \\
\text { agrowisata }\end{array}$ & 14 \\
\hline 2. & Kerjasama antar masyarakat & 16 \\
\hline 3. & Kerjasama masyarakat dengan investor (swasta) & 8 \\
\hline 4. & Kerjasama masyarakat dengan pemerintah & 21 \\
\hline 5. & $\begin{array}{l}\text { Menggunakan transportasi umum untuk menuju } \\
\text { kawasan agrowisata seperti bus atau angkutan desa }\end{array}$ & 14 \\
\hline 6. & $\begin{array}{l}\text { Menggunakan kendaraan pribadi untuk menuju } \\
\text { kawasan agrowisata }\end{array}$ & 25 \\
\hline 7. & $\begin{array}{l}\text { Produk agrowisata berupa produk olahan hasil } \\
\text { pertanian }\end{array}$ & 41 \\
\hline 8. & $\begin{array}{l}\text { Tidak perlu mempertimbangkan objek wisata lain } \\
\text { dalam mengembangan agrowisata }\end{array}$ & 20 \\
\hline
\end{tabular}

Sumber: Hasil analisis, 2017

4. Validasi

Dari 32 kriteria yang tersisa dilakukan pengujian validasi kriteria dengan menghitung nilai Koefisien Reprodusibilitas (Kr) dan Koefisien Skalabilitas (Ks). Kriteria dapat dianggap baik jika hasil perhitungan $\mathrm{Kr}>0.9$ dan $\mathrm{Ks}>0.6$ [7][8]. Pada proses perhitungan ini digunakan alat bantu analisis yang disebut SKALO. Program ini merupakan alat bantu analisis skala guttman [9]. Setelah dilakukan pengolahan, maka didapatkan hasil perhitungan 32 kriteria yaitu $\mathrm{Kr}=0.873$ dan $\mathrm{Ks}=0.746$, dari hasil tersebut maka nilai $\mathrm{Kr}$ belum mencapai 0.9 sehingga belum memenuhi. Maka perlu dilakukan pereduksian kriteria, dimana kriteria yang direduksi adalah kriteria yang memiliki skor terendah dengan syarat setiap variabel harus memiliki kriteria, sehingga menjadi 31 kriteria. Kriteria yang tereduksi ialah pada variabel atraksi yaitu terdapat outbond dan kegiatan permainan alam, dengan skor $50 \%$. Hasil perhitungan 31 kriteria yaitu $\mathrm{Kr}=0.896$ dan $\mathrm{Ks}=0.792$, dari hasil ini nilai $\mathrm{Kr}$ juga belum mencapai 0.9 sehingga belum memenuhi. Dilakukan kembali pereduksian kriteria sehingga menjadi 30 kriteria, kriteria yang tereduksi ialah pada variabel atraksi yaitu menyuguhkan kesenian/tradisi lokal, dengan skor $61 \%$. hasil perhitungan 30 kriteria yaitu $\mathrm{Kr}=0.91$ dan $\mathrm{Ks}=0.82$, nilai ini sudah memenuhi sehingga 30 kriteria terpilih dapat dianggap baik dan valid.

5. Kriteria Terpilih

Kriteria pengembangan agrowisata di Kecamatan Sukapura Kabupaten Probolinggo ialah sebagai berikut:

Tabel 4.

Kriteria Terpilih Pengembangan Agrowisata di Kecamatan Sukapura

\begin{tabular}{|c|c|c|c|}
\hline No & Variabel & No. & Kriteria \\
\hline \multirow[t]{3}{*}{1.} & Atraksi & 1. & $\begin{array}{l}\text { Memiliki keindahan alam dan hamparan } \\
\text { lahan pertanian }\end{array}$ \\
\hline & & 2. & $\begin{array}{l}\text { Menujukan budaya petani dan aktivitas unik } \\
\text { dari pertanian }\end{array}$ \\
\hline & & 3. & $\begin{array}{l}\text { Menyuguhkan makanan unik penduduk } \\
\text { local }\end{array}$ \\
\hline 2. & $\begin{array}{l}\text { Jenis } \\
\text { Komoditas } \\
\text { Pertanian }\end{array}$ & 4. & $\begin{array}{l}\text { Terdapat beragam jenis tanaman pada } \\
\text { kawasan agrowisata }\end{array}$ \\
\hline \multirow[t]{12}{*}{3.} & Fasilitas & 5. & Ketersediaan pos keamanan \\
\hline & & 6. & Ketersediaan tempat parkir \\
\hline & & 7. & $\begin{array}{l}\text { Ketersediaan rambu-rambu petujuk arah dan } \\
\text { jalan }\end{array}$ \\
\hline & & 8. & $\begin{array}{l}\text { Ketersediaan kantor pusat informasi dan } \\
\text { pelayanan }\end{array}$ \\
\hline & & 9. & Ketersediaan tempat sampah \\
\hline & & 10. & Ketersediaan toilet/kamar mandi \\
\hline & & 11. & 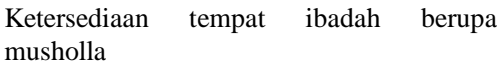 \\
\hline & & 12. & $\begin{array}{l}\text { Ketersediaan hotel/penginapan/tempat } \\
\text { peristirahatan }\end{array}$ \\
\hline & & 13. & $\begin{array}{l}\text { Ketersediaan kios cenderamata/kios } \\
\text { oleh-oleh }\end{array}$ \\
\hline & & 14. & Ketersediaan ATM \\
\hline & & 15. & Ketersediaan pos kesehatan/P3K \\
\hline & & 16. & Ketersediaan restoran/kedai makanan/cafe \\
\hline 4. & Kerjasama & 17. & $\begin{array}{l}\text { Kerjasama antara masyarakat, pemerintah } \\
\text { dan investor (swasta) }\end{array}$ \\
\hline \multirow[t]{3}{*}{5.} & $\begin{array}{l}\text { Sikap \& } \\
\text { Keramahan }\end{array}$ & 18. & $\begin{array}{l}\text { Memiliki kemampuan dalam berkomunikasi } \\
\text { yang baik dengan wisatawan }\end{array}$ \\
\hline & Masyarakat & 19. & $\begin{array}{l}\text { Memiliki kemampuan dalam branding/ } \\
\text { promosi kawasan agrowisata }\end{array}$ \\
\hline & & 20. & $\begin{array}{l}\text { Memiliki kemampuan dalam mengelola } \\
\text { kegiatan agrowisata }\end{array}$ \\
\hline 6. & $\begin{array}{l}\text { Transportasi \& } \\
\text { Aksesibilitas }\end{array}$ & 21. & $\begin{array}{l}\text { Menggunakan kendaraan wisata untuk } \\
\text { menuju kawasan agrowisata seperti jeep dan } \\
\text { lain sebagainya }\end{array}$ \\
\hline \multirow[t]{4}{*}{7.} & Infrastruktur & 22. & Perlu terjangkau sinyal telepon selelur \\
\hline & & 23. & Perlu ketersediaan sumber listrik \\
\hline & & 24. & Perlu ketersediaan sumber air \\
\hline & & 25. & Tersedia jaringan jalan \\
\hline \multirow[t]{3}{*}{8.} & Ketahanan & 26. & Memiliki jalur evakuasi \\
\hline & Bencana & 27. & Memiliki tempat melindungi bibit tanaman \\
\hline & & 28. & $\begin{array}{l}\text { Sumber daya manusia memiliki kemampuan } \\
\text { dalam situasi tanggap bencana }\end{array}$ \\
\hline 9. & Produk Agro & 29. & $\begin{array}{l}\text { Produk agrowisata berupa hasil panen } \\
\text { pertanian seperti sayuran/ buah-buahan. }\end{array}$ \\
\hline
\end{tabular}

10. Objek Wisata 30. Mempertimbangkan keberadaan objek Lain wisata lain, baik dalam satu kawasan wisata maupun tidak (lingkup satu desa)

Sumber: Hasil Analisis, 2017

\section{KESIMPULAN}

Pada penelitian ini bertujuan untuk menentukan kriteria pengembangan agrowisata di Kecamatan Sukapura Kabupaten Probolinggo. Berikut hasil yang diperoleh dari penelitian ini : 
1. Variabel yang bekaitan dengan pengembangan agrowisata di Kecamatan Sukapura Kabupaten Probolinggo ialah atraksi, jenis komoditas pertanian, fasilitas, infrastruktur, kerjasama, sikap \& keramahan masyarakat, transportasi \& aksesibilitas, ketahanan bencana, produk agro, dan objek wisata lain.

2. Kriteria pengembangan agrowisata di Kecamatan Sukapura ditentukan tiap variabel yang terdiri dari Atraksi dengan kriteria meliputi: pada kawasan agrowisata harus memiliki keindahan alam dan hamparan lahan pertanian; menunjukan budaya petani dan aktivitas unik dari pertanian; dan menyuguhkan makanan unik penduduk lokal. Jenis Komoditas Pertanian dengan kriteria, terdapat beragam jenis tanaman. Fasilitas dengan kriteria meliputi tersedianya pos keamanan; tempat parkir; rambu-rambu petunjuk arah dan jalan; kantor pusat informasi dan pelayanan; tempat sampah; toilet/kamar mandi; tempat ibadah berupa musholla; hotel/penginapan/ tempat peristirahatan; kios cenderamata/kios oleh-oleh; ATM; pos kesehatan; dan restoran/kedai makanan dan café. Kerjasama dengan kriteria yaitu terdapat kerjasama antara antar masyarakat, pemerintah dan investor (swasta). Sikap \& keramahan masyarakat dengan kriteria meliputi memiliki kemampuan dalam berkomunikasi yang baik dengan wisatawan; memiliki kemampuan dalam branding/ promosi; dan kemampuan mengelola agrowisata. Transportasi \& Aksesibilitas dengan kriteria yaitu mengunakan kendaraan wisata untuk menuju kawasan agrowisata seperti jeep dan lain sebagainya. Infrastruktur dengan kriteria yaitu terjangkau sinyal telepon seluler; tersedia sumber listrik, sumber air dan jaringan jalan. Ketahanan bencana dengan kriteria yaitu memiliki jalur evakuasi; memiliki tempat untuk melindungi bibit tanaman; dan memiliki SDM yang tanggap bencana. Produk Agro dengan kriteria berupa produk hasil panen pertanian seperti sayuran atau buah-buahan. Objek Wisata Lain dengan kriteria yaitu mempertimbangkan keberadaan objek wisata lain dalam mengembangkan kawasan agrowisata, baik dalam satu kawasan wisata maupun tidak (lingkup satu desa).

\section{DAFTAR PUSTAKA}

[1] Badan Perencanaan dan Pembangunan Daerah Kabupaten Probolinggo, Rencana Tata Ruang Kabupaten Probolinggo Tahun 2010-2029. Probolinggo: Pemkab Probolinggo, 2016.

[2] Badan Perencanaan dan Pembangunan Daerah Kabupaten Probolinggo, Rencana Pengembangan Kawasan Agropilitan Kabupaten Probolinggo Tahun 2006-2016. Probolinggo: Pemkab Probolinggo, 2016.

[3] Badan Pusat Statistik, Kecamatan Sukapura dalam Angka 2016. Probolinggo: BPS, 2016.

[4] Badan Perencanaan dan Pembangunan Daerah Kabupaten Probolinggo, Rencana Aksi Pengembangan Kepariwisataan Kabupaten Probolinggo Tahun 2010-2029. Probolinggo: Pemkab Probolinggo, 2016.

[5] D. Sugiyono, Prof, Metode Penelitian Pendidikan (Pendekatan Kuantitatif, Kualitatif, $R \& D)$ ). Bandung: Alfabeta, 2006.

[6] I. G. B. Rai Utama, Agrowisata sebagai pariwisata alternative di Indonesia. Denpasar, 2012.

[7] S. E. M.Singarimbun, Metode Peneltian Survai. LP3SE, 1997.

[8] R. D. Munggaran, Pemanfaatan Open Source Sofware Pendidikan Oleh Mahasiswa Dalam Rangka Implementasi Undang-Undang No. 19 Tahun 2002 Tentang Hak Cipta. UPI, 2012.

[9] W. Widhiarso, "SKALO-Program Analisis Skala Guttman," UGM, 2011. 